\title{
Neurodevelopmental Evaluation of Term Newborns with Significant Hyperbilirubinemia
}

\author{
Belirgin Hiperbilirubinemili Term Yenidoğanların Nörogelișimlerinin \\ Değerlendirilmesi
}

\author{
Gamze Özgürhan, D Serdar Cömert
}

University of Health Sciences Turkey, İstanbul Training and Research Hospital, Clinic of Pediatrics, İstanbul, Turkey

\begin{abstract}
Introduction: When bilirubin attains high levels, it can lead to different degrees of brain damage. In this study, we aimed to evaluate the neurodevelopment status of term newborns treated for hyperbilirubinemia in the neonatal period.

Methods: The study group consisted of 48 children with total bilirubin $>22 \mathrm{mg} / \mathrm{dL}$ in the neonatal period. The study group was compared with 50 healthy children determined as the control group. Detailed physical examination of all the children was performed and anthropometric measurements were taken. Previous hospitalisation data of the study group were examined, and the socio-demographic data of the parents were also obtained. All the children underwent neurodevelopmental screening with the Denver II Developmental Screening test (DDST).

Results: No statistically significant difference was found between the hyperbilirubinaemia group and control group in terms of the male/female ratio, age, weight, height, body mass index and prophylactic iron use. Maternal and paternal demographic data were compared, and there was no significant difference. The general results of the DDST were compared, and significant neurodevelopmental retardation was found in the study group $(p<0.001)$. For both groups, the DDST development areas were compared; language development $(p<0.001)$ and fine motor development $(p=0.046)$ were delayed in the study group. In the receiver operating characteristic curve analysis, the risk of developmental retardation was found to be higher in newborns with bilirubin values greater than $23.5 \mathrm{mg} / \mathrm{dL}$ $(p=0.009)$.
\end{abstract}

Conclusion: Significant hyperbilirubinaemia is an important risk factor for the retarded child development. Therefore, developmental screening tests should be performed at regular intervals for the early detection of developmental delays and to start the appropriate treatment.

Keywords: Neonatal jaundice, hyperbilirubinemia, neurodevelopment, language development, Denver II

\section{öZ}

Amaç: Bilirubin yüksek seviyelere ulaştığında farklı derecelerde beyin hasarına yol açabilir. Bu çalıșmada yenidoğan döneminde hiperbilirubinemi nedeni ile tedavi edilmiş term bebeklerin nörogelișim durumları değerlendirildi.

Yöntemler: Çalıșma grubu olarak yenidoğan döneminde total bilirubini $22 \mathrm{mg} / \mathrm{dL}$ 'nin üzerinde olan ve term olarak doğmuş 48 çocuk ve kontrol grubu olarak 50 sağlıklı çocuk karşılaştırıldı. Tüm çocıkların ayrıntılı fizik muayenesi yapıldı ve antropometrik ölçümleri alındı. Çalıșma grubuna ait eski yatış verileri incelendi. Anne ve babaya ait sosyo-demografik veriler sorgulandı. Tüm çocuklara Denver II Gelişimsel Tarama testi yapıldı (DGTT).

Bulgular: Hiperbilirubinemi grubu ve kontrol grubu arasında erkek/kız oranı, yaş, ağırlık, boy, vücut kitle indeksi, profilaktik demir kullanımı açısından istatistiksel olarak fark bulunmadı. Maternal ve paternal demografik veriler karșılaștırıldığında anlamlı fark yoktu. DGTT genel sonuçları karşılaştırıldığında, çalışma grubunda belirgin nörogelișim geriliği saptandı $(p<0,001)$. Her iki grup DGTT gelișim alanları karşılaștırıldığında çalışma grubunda dil $(p<0,001)$ ve ince motor $(p=0,046)$ gelişimi geri bulundu. Yapılan receiver operating characteristic curve analizinde $23,5 \mathrm{mg} / \mathrm{dL}$ üzerindeki bilirubin değerlerine sahip olan yenidoğanlarda gelișim geriliği görülme riski daha fazla bulundu $(p=0,009)$.

Sonuç: Belirgin hiperbilirubinemi çocuğun gelișimi açısından önemli bir risk faktörüdür. Bu nedenle gelișimsel gecikmenin erken tespiti ve uygun tedaviye başlanması için gelișimsel tarama testleri düzenli aralıklarla yapılmalıdır.

Anahtar Kelimeler: Yenidoğan sarılı̆̆ı, hiperbilirubinemi, nörogelişim, dil gelişimi, Denver II

Cite this article as/Atıf: Özgürhan G, Cömert S. Neurodevelopmental Evaluation of Term Newborns with Significant Hyperbilirubinemia. İstanbul Med J 2020; 21(5): 370-4.

(C) Copyright 2020 by the University of Health Sciences Turkey, Istanbul Training and Research Hospital/Istanbul Medical Journal published by Galenos Publishing House

(C) Telif Hakkı 2020 Sağıı Bilimleri Üniversitesi Istanbul Ĕgitim ve Araştırma Hastanesi/Istanbul Tıp Dergisi, Galenos Yayınevi tarafından basılmıștır. 
Özgürhan and Cömert. The Effect of Hyperbilirubinemia on Neurodevelopment

\section{Introduction}

In the first week of life, high bilirubin level is an important indicator because free bilirubin can cross the blood brain barrier. It is well known that bilirubin causes serious brain damage when it attains very high levels. Damage to the central nervous system varies depending on the bilirubin level. This neurological effect has a broad spectrum, from mild impacts such as isolated auditory neuropathy, movement disorders, dystonia, cognitive disorders, mild mental retardation to much more severe impacts such as severe neuromotor deficits due to acute bilirubin encephalopathy and auditory sequelae (1-3).

Today, most patients with high bilirubin levels do not experience neurological damage due to the modern treatment methods and because patients can benefit more from medical services $(4,5)$. However, there are few patients who still develop mild neurological damage, and detecting these patients is critical. Essentially, the population in which we can make a difference is among patients with little damage. Therefore, in addition to the hearing assessment, which is usually what we pay the most attention to during follow-up, neurodevelopmental screening tests should be carried out diligently (6-8).

In our study, we made a neurodevelopmental evaluation of newborns with different bilirubin levels. We used the Denver II Developmental Screening test (DDST), which included personal-social, fine motor, language and gross motor assessments.

\section{Methods}

This prospective and comparative study was approved by the local ethics committee (approval number: GOKAEK/2017-550, date: 08.02.2017). All the participants were informed verbally and in writing about the study and their written consents were obtained.

\section{Study Groups}

The study included two groups: study group and control group. The study group consisted of 48 cases who were treated for a high bilirubin (total bilirubin) level (>22 mg/dL) and were born at 38 to 42 gestational weeks. Seventy-seven patients who were treated in our neonatal intensive care unit due to hyperbilirubinemia between 2015 and 2016 (>22 mg/dL) were identified. Those who were reachable by phone were included in the study. The control group consisted of 50 healthy children who visited our outpatient clinic. Exclusion criteria included preterm births (<38 weeks), hypoxic delivery, intrauterine growth retardation, major congenital malformation, hospitalisation for any reason, hearing problems, any chronic disease and maternal disease during pregnancy.

Detailed physical examinations and neurological examinations of the children were performed. Weight, height and body mass index (BMI) of all the cases were recorded. Mothers were asked if they gave their children iron prophylaxis between 4 and 12 months. Children's Hearing tests (Brain stem evoked response audiometry - BERA) were performed. The hospitalisation files of the children in the study group were examined and the data were recorded. Socio-demographic data of the parents was also obtained.

\section{Neurodevelopmental Assessment}

DDST was used in the neurodevelopmental evaluation of the patients. The same paediatrician who had the certificate evaluated all the children. Denver developmental screening test, which was defined by Frankenburg and Dodds in 1967, was revised in 1990 as Denver II. In our study, we used the version of this test standardised by Yalaz et al. (9) in 2009.

DDST is applied to 0-6 years old children with a healthy appearance. It consists of 134 items created to evaluate the ability in 4 developmental areas according to age: personal-social (21 items), fine motor (33 items), language (42 items) and gross motor (38 items). The test results in 4 possible evaluations: normal, abnormal, suspicious and non-testable.

\section{Statistical Analysis}

The Shapiro-Wilk test was used to perform normality control on the histogram, Q-Q plot and box plot charts. Data were expressed as median, minimum, maximum, frequency and percentage. The measurement variables between the two groups were analysed with the Mann-Whitney U test. Receiver operating characteristic (ROC) analysis was performed. Diagnostic tests (sens., Spe., PPV, NPV, Accuracy) and 95\% confidence intervals were given. Nominal variables were evaluated with Yates corrected chi square test with Yates correction and Fisher's exact probability tests. Odds ratio values and 95\% confidence intervals were calculated. The limit of significance was taken as $p<0.05$ and bidirectional. The analyses were performed using NCSS 10 (2015. Kaysville, Utah, USA) software program.

\section{Results}

This study included 48 newborns with hyperbilirubinaemia and 50 healthy children. There was no significant difference between the hyperbilirubinaemia and control groups in terms of the female/male ratio $(p=0.54)$. The average age in the study group was $37.3 \pm 8.3$ months, the average weight was $14.8 \pm 2.6 \mathrm{~kg}$, the average height was $100.2 \pm 7.2$ $\mathrm{cm}$, and the average BMI was $14.8 \pm 1.1$. The mean age in the control group was $41.7 \pm 10.2$ months, the average weight was $14.6 \pm 2.2 \mathrm{~kg}$, the average height was $101.8 \pm 6.8 \mathrm{~cm}$, and the average BMI was $14.1 \pm 1.1$. In terms of age, weight, height and BMI, no significant difference was found between the study and control groups $(p=0.14),(p=0.66),(p=0.42)$ and $(p=0.13)$, respectively. There was no difference between the use of iron prophylaxis in both groups $(p=0.85)$ (Table 1).

Hospital records of the children in the hyperbilirubinaemia group were examined. The average gestational age was $38.7 \pm 0.4$ weeks, mean birth weight was $3185 \pm 335 \mathrm{~g}$ and the duration of hospitalisation was $3.22 \pm 1.4$ days. The time of admission was found to be $4.3 \pm 2.4$ days after birth. The cause of hyperbilirubinaemia was $\mathrm{ABO}$ incompatibility in 17 patients, Rh incompatibility in 4 patients, G6PDH deficiency in 5 patients and weight loss in 3 patients. The cause of the hyperbilirubinaemia was not found in 19 patients. Blood exchange was performed in 2 patients, IVIG treatment was applied to 9 patients, and phototherapy was given to all the patients.

The maternal and paternal demographic data of the study and control groups were compared. No statistically significant difference was found 
between the two groups in terms of maternal and paternal age and education level, number of children in the family and monthly income (Table 2).

DDST general results were evaluated. There was a statistically significant difference between the two groups in terms of neurodevelopment. Neurodevelopment was significantly lower in the hyperbilirubinaemia group $(\mathrm{p}<0.001)$ (Table 3$)$.

DDST results were evaluated according to developmental areas. There was no statistical difference in the personal-social $(p=0.26)$ and gross motor $(p=0.31)$ areas in both groups. In the hyperbilirubinaemia group, the developmental delay was statistically significant in the language and fine motor areas $(p<0.001),(p=0.046)$ respectively (Table 4$)$.

ROC curve analysis was performed to determine the cut-off value of total bilirubin in predicting developmental delay. Total bilirubin cut-off value was found to be $23.5 \mathrm{mg} / \mathrm{dL}(\mathrm{p}=0.009)$ (Figure1).

\section{Discussion}

Hyperbilirubinaemia, one of the most common problems of the neonatal period, is critical because it affects brain development when the bilirubin level exceeds a certain threshold value.

Bilirubin toxicity has been associated with many conditions such as neurodevelopmental delays, cognition-speech-language development, attention deficit-hyperactivity disorder and autism (6-10).

\begin{tabular}{|c|c|c|c|}
\hline Characteristics & $\begin{array}{l}\text { Study group } \\
(n=48) \%\end{array}$ & $\begin{array}{l}\text { Control group } \\
(n=50) \%\end{array}$ & p \\
\hline Gender (male/female) & (26) 54/(22) 46 & (23) 48/(27) 54 & 0.54 \\
\hline Age (months) & $37.3 \pm 8.3$ & $41.7 \pm 10.2$ & \multirow[b]{2}{*}{0.14} \\
\hline Mean \pm SD & $(24-58)$ & $(25-62)$ & \\
\hline Height $(\mathrm{cm})$ & $100.2 \pm 7.2$ & $101.8 \pm 6.8$ & \multirow{2}{*}{0.42} \\
\hline Mean $\pm S D$ & $(83-120)$ & $(91-120)$ & \\
\hline Weight (kg) & $14.8 \pm 2.6$ & $14.6 \pm 2.2$ & \multirow{2}{*}{0.66} \\
\hline Mean \pm SD & $(9-25)$ & $(11.8-23.7)$ & \\
\hline BMI & $14.8 \pm 1.1$ & $14.1 \pm 1.1$ & \multirow{2}{*}{0.13} \\
\hline Mean \pm SD & $(12.6-17.4)$ & $(11.8-17.0)$ & \\
\hline \multicolumn{3}{|l|}{ Iron intake, n (\%) } & \multirow{4}{*}{0.85} \\
\hline None & (9) 18.8 & (8) 16 & \\
\hline Regular & (28) 58.3 & (32) 64 & \\
\hline Irregular & (11) 22.9 & (10) 20 & \\
\hline
\end{tabular}

SD: Standard deviation, BMI: body mass index, statistically significant increased values $(p<0.05), n$ : number of patients
We evaluated babies with hyperbilirubinaemia using the DDST. In our study, when we compared the patients with hyperbilirubinemia with the control group, we found that their neurodevelopment was significantly retarded $(p<0.001)$. The literature suggests that there is a significant relationship between neonatal hyperbilirubinemia and neurodevelopmental delay, but this relationship seems quite complicated. In a recent study, the factors affecting neurodevelopmental delay in preterm and term babies were examined. In preterm infants, the most important risk factors were intensive care period, ototoxic drug use, mechanical ventilation and hyperbilirubinemia, while in term

Table 2. Maternal and paternal demographic characteristics

\begin{tabular}{|c|c|c|c|}
\hline Characteristics & $\begin{array}{l}\text { Study group } \\
(n=48) \%\end{array}$ & $\begin{array}{l}\text { Control group } \\
(n=50) \%\end{array}$ & $p$ \\
\hline Maternal age & $28.6 \pm 6.8$ & $28.9 \pm 5.3$ & \multirow{2}{*}{0.57} \\
\hline Mean \pm SD & $(17-46)$ & $(19-40)$ & \\
\hline \multicolumn{3}{|l|}{ Maternal education } & \multirow{6}{*}{0.33} \\
\hline Illiterate & (3) 6 & (0) 0 & \\
\hline Primary school & (28) 58 & (33) 66 & \\
\hline Secondary school & (8) 17 & (6) 12 & \\
\hline High school & (6) 13 & (9) 18 & \\
\hline University & (3) 6 & (2) 4 & \\
\hline Paternal age & $31.7 \pm 7.13$ & $34.3 \pm 7.5$ & \multirow{2}{*}{0.16} \\
\hline Mean \pm SD & $(20-53)$ & $(19-53)$ & \\
\hline \multicolumn{3}{|l|}{ Paternal education } & \multirow{6}{*}{0.35} \\
\hline Illiterate & (2) 4 & (0) 0 & \\
\hline Primary school & (23) 48 & (25) 50 & \\
\hline Secondary school & (13) 27 & (9) 18 & \\
\hline High school & (8) 17 & (11) 22 & \\
\hline University & (2) 4 & (5) 10 & \\
\hline \multicolumn{3}{|l|}{ Number of children } & \multirow{6}{*}{0.10} \\
\hline 1 & (20) 42 & (10) 20 & \\
\hline 2 & (10) 21 & (22) 44 & \\
\hline 3 & (10) 21 & (11) 22 & \\
\hline 4 & (6) 12 & (5) 10 & \\
\hline 5 & (2) 4 & (2) 4 & \\
\hline \multicolumn{3}{|c|}{ Monthly income (Turkish Liras) } & \multirow{4}{*}{0.96} \\
\hline$<2000$ & (12) 25 & (12) 24 & \\
\hline $2000-5000$ & (32) 67 & (33) 66 & \\
\hline$>5000$ & (4) 8 & (5) 10 & \\
\hline
\end{tabular}

SD: Standard deviation, statistically significant increased values $(p<0.05), n$ : number of the patients

Table 3. Denver II developmental screening test general results

\begin{tabular}{|l|l|l|l|}
\hline Results & $\begin{array}{l}\text { Study group } \\
\mathbf{n = 4 8}(\mathbf{4})\end{array}$ & $\begin{array}{l}\text { Control group } \\
\mathbf{n = 5 0}(\mathbf{\%})\end{array}$ & OR $(\mathbf{9 5 \%} \mathbf{C I})$ \\
\hline Normal & $21(44)$ & $43(86)$ & $\mathbf{p}$ \\
\hline Suspicious & $16(33)$ & $5(10)$ & $7.89(2.9-21.1)$ \\
\hline Abnormal & $11(23)$ & $2(4)$ & $<0.001$ \\
\hline Non-testable & $0(0)$ & $0(0)$ & \\
\hline
\end{tabular}

Statistically significant increased values $(\mathrm{p}<0.05)$, OR: odds ratio, $\mathrm{Cl}$ : confidence interval, $\mathrm{n}$ : number of patients 
Table 4. Denver II developmental screening test results according to the developmental areas

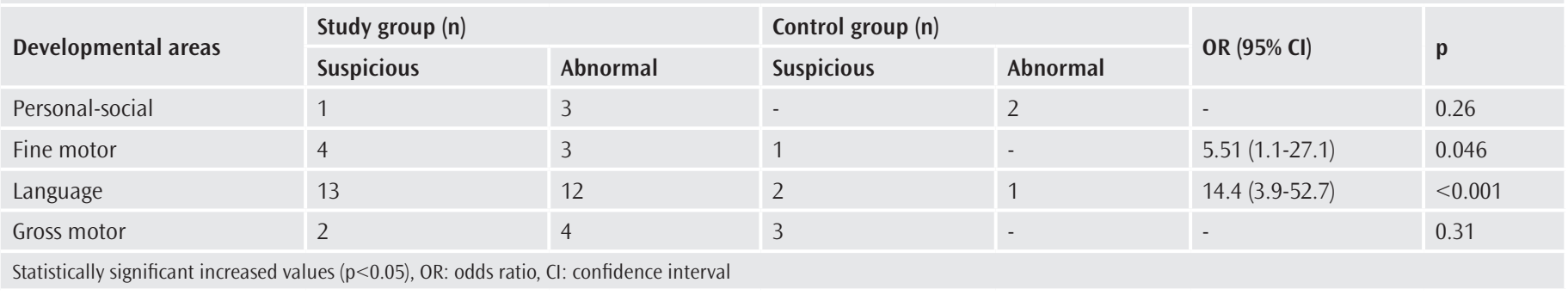

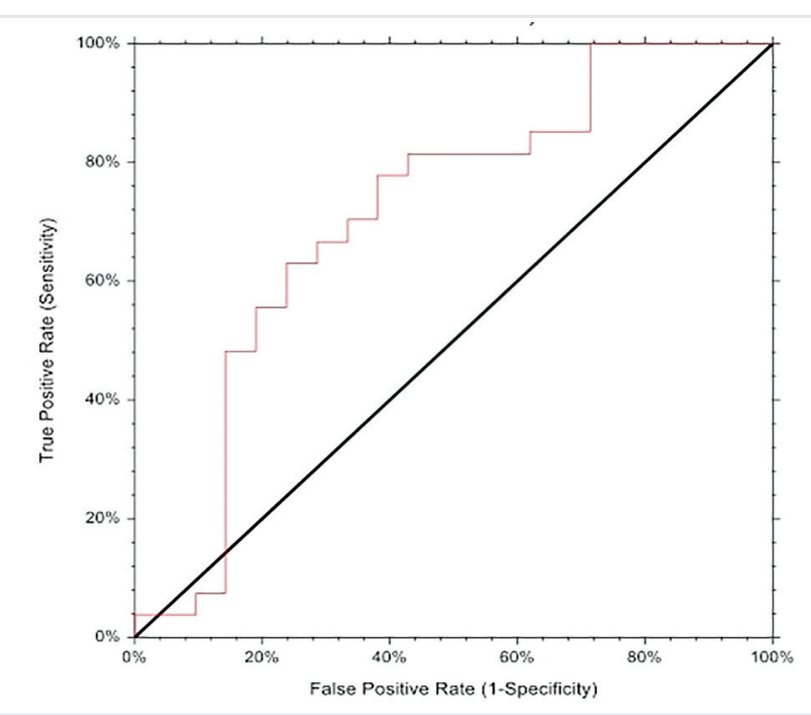

Figure 1. ROC curve analysis; serum total bilirubin cut-off value to predict developmental delay ( $p=0.009$ ), (Empirical estimate of AUC: 0.711, AUC's SD: 0.081 , Lower $95 \%$ Cl: 0.515, Upper 95\% Cl: 0.836)

ROC: Receiver operating characteristic, AUC: area under curve, Cl: confidence interval, SD: standard deviation

infants, the risk factors were hyperbilirubinemia and Apgar score $(11,12)$. Another study in term babies found that the higher the bilirubin level, the more negatively the development was affected (13).

Preterm infants are more sensitive to hyperbilirubinaemia. Therefore, the relationship between hyperbilirubinaemia and developmental retardation has been studied mostly in preterm infants. In the many studies conducted in this group, the effect of hyperbilirubinaemia on developmental delay has been found to be quite pronounced (14-17).

As the bilirubin level in the blood increases, newborns are more affected by its possible toxic effects. In our study, newborns with a total bilirubin level greater than $23.5 \mathrm{mg} / \mathrm{dL}$ were found to be more at risk in terms of neurodevelopmental delay. In a study with the Baroda developmental screening test, they found that neurodevelopment delay was more likely in term babies with a total bilirubin level greater than $22 \mathrm{mg} / \mathrm{dL}$ (13).

DDST is a very reliable and widely used test in evaluating the neurodevelopment of children aged 0-6 years. It has been used to evaluate neurodevelopment in different case groups such as adenotonsillar hypertrophy, congenital heart disease and babies from pre-eclamptic mothers (18-20).

In our study, there was a marked delay in language development in the hyperbilirubinaemia group $(p<0.001)$. In many studies, the effect of hyperbilirubinemia on neurodevelopment has been investigated, but only the impact on hearing has been revealed. None of these studies focused on the relationship between speech delay and hyperbilirubinaemia. There is limited information in the literature about the effect of hyperbilirubinaemia on hearing and language development $(18,19,21)$.

In our study, a statistically significant fine motor developmental delay was found in the hyperbilirubinaemia group compared to the control group $(p<0.046)$. The link between motor retardation and dyskinetic cerebral palsy is well known in newborns exposed to high bilirubin toxicity. However, the effect of exposure to low-moderate bilirubin levels on motor development is not fully understood. More research is needed to understand motor disorders that can be caused by neonatal hyperbilirubinaemia. Movement disorders and cerebral palsy may also develop in preterm babies exposed to low-to-moderate bilirubin levels $(22,23)$.

There was no significant difference in personal-social and gross motor development between the two groups in our study.

Factors such as the paternal and maternal level of education level and the income level of the family can play an important role in the child's development. In a large-scale study, maternal education has been shown to have a significant effect on the language and fine motor development of preschool children. It was also found that the mother was more effective than the father in impacting the development of the child in early childhood (24-26). In our study, no difference was found between the two groups in terms of the level of education of the parents, the income level of the family and the number of children in the family.

The fact that our study was conducted with a small number of cases can be considered as a limitation. However, the exclusion criteria have been expanded to obtain more accurate results. It is also an advantage that the same person evaluated all children, and the study was done prospectively.

\section{Conclusion}

In children without significant developmental disorders, cases of mild neurological damage may not be detected by normal physical examination. In children treated for significant hyperbilirubinaemia, developmental screening tests should be performed at regular intervals, in addition to the detailed systemic examination and hearing testing. Early detection of developmental delays in children is essential for initiating the right treatment in a timely manner. 


\section{Ethics}

Ethics Committee Approval: This prospective and comparative study was approved by the local ethics committee (approval number: GOKAEK/2017-550, date: 08.02.2017).

Informed Consent: Informed consent was obtained from all patients.

Peer-review: Externally peer-reviewed.

Authorship Contributions: Concept - G.Ö., S.C.; Design - G.Ö., S.C.; Data Collection or Processing - G.Ö.; Analysis or Interpretation - G.Ö., S.C.; Literature Search - G.Ö.; Writing - G.Ö.

Conflict of Interest: No conflict of interest was declared by the authors.

Financial Disclosure: The authors declared that this study received no financial support.

\section{References}

1. Johnson L, Brown AK, Bhutani VK. BIND-a clinical score for bilirubin induced neurologic dysfunction in newborns. Pediatrics Suppl 1999; 104: 746-7.

2. Shapiro SM. De nition of the clinical spectrum of kernicterus and bilirubin induced neurologic dysfunction (BIND). J Perinatol 2005; 25: 54-9.

3. Shapiro SM. Kernicterus. In: Stevenson DK, Maisels MJ, Watchko JF, eds. Care of jaundiced neonate. New York: McGraw-Hill 2012: 229- 42.

4. Stevenson DK, Fanarof AA, Maisels MJ, Young BW, Wong RJ, Vreman HJ, et al. Prediction of hyperbilirubinemia in near-term and term infants. Pediatrics 2001; 108: 31-9.

5. American Academy of Pediatrics, Provisional Committee for Quality Improvement. Practice parameter: management of hyperbilirubinemia in the healthy term newborn. Pediatrics 1994; 94: 558-65.

6. Volpe JJ. Neurology of the Newborn, 4th Edition. Philadephia: WB Saunders; 2001.

7. Bhutani VK, Johnson LH, Maisels JM, Newman TB, Phibbs C, Stark AR, et al. Kernicterus: Epidemiological strategies for its prevention through systemsbased approaches. J Perinatol 2004; 24: 650-62.

8. L. Wusthoff CJ, Loe IM. Impact of bilirubin-induced neurologic dysfunction on neurodevelopmental outcomes. Semin Fetal Neonatal Med 2015; 20: 52-7.

9. Yalaz K, Anlar B, Bayoğlu BU. Denver II gelișimsel tarama testi türkiye standardizasyonu. Gelișimsel çocuk nörolojisi derneği; 2009.

10. Maimburg RD, Bech BH, Vaeth M, Moller-Madsen B, Olsen J. Neonatal jaundice, autism, and other disorders of psychological development. Pediatrics 2010; 126: 872-8.

11. Watchko JF, Tribelli C. Bilirubin-induced neurologic damage- mechanisms and management approaches. N Engl J Med 2013; 369: 2021-30.
12. Nascimento GB, Kessler TM, Ramos de Souza AP, Costa I, Moraes AB. Risk indicators for hearing loss and language acquisition and their relationship with socioeconomic, demographic and obstetric variables in preterm and term babies. Codas 2020; 32: e20180278.

13. Thirunavukkarasu AB, Vishnu BB, Noyal MJ. Association between peak serum bilirubin and neurodevelopmental outcomes in term babies with hyperbilirubinemia. Indian J Pediatr 2012; 79: 202-6.

14. Amin SB. Clinical assessment of bilirubin-induced neurotoxicity in premature infants. Semin Perinatol 2004; 28: 340-7.

15. Oh W, Tyson JE, Fanaroff AA, Vohr BR, Perritt R, Stoll BJ, et al. Association between peak serum bilirubin and neurodevelopmental outcomes in extremely low birth weight infants. Pediatrics 2003; 112: 773-9.

16. Graziani LJ, Mitchell DG, Kornhauser M, Pidcock FS, Merton DA, Stanley C, et al. Neurodevelopment of preterm infants: neonatal neurosonographic and serum bilirubin studies. Pediatrics 1992; 89: 229-34.

17. Hack M, Wilson-Costello D, Friedman H, Taylor GH, Schluchter M, Fanaroff AA. Neurodevelopment and predictors of outcomes of children with birth weights of less than 1000 g: 1992-1995. Arch Pediatr Adolesc Med 2000; 154: 725-31.

18. Ozmen A, Terlemez S, Tunaoglu FS, Soysal S, Pektas A, Cilsal E, et al. Evaluation of Neurodevelopment and Factors Affecting it in Children with Acyanotic Congenital Cardiac Disease. Iran J Pediatr 2016; 26: e3278.

19. Soylu E, Soylu N, Polat C, Sakallıoğlu O, Uçur, O, Bozdoğan G. Developmental delays in preschool children with adenotonsillar hypertrophy. Kulak Burun Bogaz Ihtis Derg 2016; 26:129-34.

20. Ertekin AA, Kapudere B, Eken MK, Ilhan G, Dırman S, Sargın MA, et al. Does aggressive and expectant management of severe preeclampsia affect the neurologic development of the infant? Int J Clin Exp Med 2015; 8: 19325-31.

21. Amin SB, Prinzing D, Myers G. Hyperbilirubinemia and Language Delay in Premature Infants. Pediatrics 2009; 123: 327-31.

22. Rose J, Vassar R. Movement Disorders Due to Bilirubin Toxicity. Semin Fetal Neonatal Med 2015; 20: 20-5.

23. Przekop A, Sanger TD. Birth-related Syndromes of Athetosis and Kernicterus. Handb Clin Neurol 2011; 100: 387-95.

24. Durmazlar N, Ozturk C, Ural B, Karaagaoglu E, Anlar B. Turkish children's performance on Denver II: Effect of sex and mother's education. Dev Med Child Neurol 1998; 40: 411-6.

25. Rowe ML, Raudenbush SW, Goldin-Meadow S. The pace of vocabular growth helps predict later vocabulary skill. Child Dev 2012; 83: 508-25.

26. Gonzalez JE, Acosta S, Davis H, Pollard-Durodola S, Saenz L, Soares D, et al. Latino maternal literacy beliefs and practices mediating socioeconomic status and maternal education effects in predicting child receptive vocabulary. Early Educ Dev 2017; 28: 78-95. 